Santa Clara University

Scholar Commons

Electrical Engineering

School of Engineering

$12-1-2001$

\title{
Spectroscopic ellipsometry and electrical studies of as-grown and rapid thermal oxidized $\mathrm{Si}_{1-\mathrm{x}-\mathrm{y}} \mathrm{Ge}_{\mathrm{x}} \mathrm{C}_{\mathrm{y}}$ films
}

W. K. Choi

W. Feng

L. K. Bera

Cary Y. Yang

Santa Clara University, cyang@scu.edu

J.Mi

Follow this and additional works at: https://scholarcommons.scu.edu/elec

\section{Recommended Citation}

W.K. Choi, W. Feng, L.K. Bera, C.Y. Yang, and J. Mi, "Spectroscopic ellipsometry and electrical studies of as-grown and rapid thermal oxidized $\mathrm{Si}_{1-\mathrm{x}-\mathrm{y}} \mathrm{Ge}_{\mathrm{x}} \mathrm{C}_{\mathrm{y}}$ films,” Journal of Applied Physics 90, 5814-5824 (2001). https:// doi.org/10.1063/1.1413715

Copyright $(92001$ American Institute of Physics Publishing. Reprinted with permission.

This Article is brought to you for free and open access by the School of Engineering at Scholar Commons. It has been accepted for inclusion in Electrical Engineering by an authorized administrator of Scholar Commons. For more information, please contact rscroggin@scu.edu. 


\title{
Spectroscopic ellipsometry and electrical studies of as-grown and rapid thermal oxidized $\mathrm{Si}_{1-x-y} \mathrm{Ge}_{x} \mathrm{C}_{y}$ films
}

\author{
W. K. Choi, ${ }^{a)}$ W. Feng, and L. K. Bera \\ Microelectronics Laboratory, Department of Electrical and Computer Engineering, National University \\ of Singapore 4 Engineering Drive 3, Singapore 117576 \\ C. Y. Yang and J. Mi \\ Microelectronics Laboratory, Santa Clara University, 500 El Camino Real, Santa Clara, California 95053
}

(Received 16 April 2001; accepted for publication 28 August 2001)

\begin{abstract}
Transmission electron microscopy results showed the formation of $\mathrm{SiC}$ precipitation in a rapid thermally oxidized (RTO) $\mathrm{Si}_{1-x-y} \mathrm{Ge}_{x} \mathrm{C}_{y}$ sample with high-C content. The spectroscopic ellipsometry results showed that the $E_{1}$ gap increased and $E_{2}$ gap decreased as the C concentration increased. For the oxidized samples, the amplitude of the $E_{2}$ transitions reduced rapidly and the $E_{1}$ transition shifted to a lower energy. The reduction in the $E_{2}$ transitions was due to the presence of the oxide layer. A high-Ge content layer and the low-C content in the RTO films accounted for the $E_{1}$ shift to lower energy. The electrical measurements showed that RTO at $800^{\circ} \mathrm{C}$ did not improve the oxide quality as compared to $1000^{\circ} \mathrm{C}$. (C) 2001 American Institute of Physics.
\end{abstract}

[DOI: $10.1063 / 1.1413715]$

\section{INTRODUCTION}

Epitaxial $\mathrm{Si}_{1-x} \mathrm{Ge}_{x} / \mathrm{Si}$ heterostructures ${ }^{1-4}$ have demonstrated impressive results for Si-based band-gap engineering. The incorporation of carbon (C) in $\mathrm{Si}_{1-x} \mathrm{Ge}_{x}$ layers allows the growth of heterostructures with well-controlled misfit strain. The growth of such layers is, however, difficult due to the high mismatch between $\mathrm{C}$ and Si lattices, low solubility of $\mathrm{C}$ in $\mathrm{Si}$, and the tendency of silicon carbide precipitation.

We have recently carried out structural ${ }^{5,6}$ and electrical ${ }^{7}$ characterizations of as-grown and rapid thermal oxidized (RTO) $\mathrm{Si}_{1-x-y} \mathrm{Ge}_{x} \mathrm{C}_{y}$ alloy films grown by rapid thermal chemical-vapor deposition (RTCVD). We found that C incorporation into the $\mathrm{Si}_{1-x-y} \mathrm{Ge}_{x} \mathrm{C}_{y}$ system can lead to compressive or tensile strain in the film. For compressive or fully compensated films, the RTO process drastically reduces the $\mathrm{C}$ content such that the oxidized films closely resemble the $\mathrm{Si}_{1-x} \mathrm{Ge}_{x}$ films. For tensile films, two broad regions, one with carbon content higher and the other lower than that required for full compensation, coexist in the oxidized films. We have also reported briefly the formation of $\mathrm{SiC}$ precipitates in the high-C content RTO samples.

The electrical results of oxides grown at $1000{ }^{\circ} \mathrm{C}$ indicated segregation of $\mathrm{Ge}$ at the $\mathrm{SiO}_{2} / \mathrm{Si}_{1-x-y} \mathrm{Ge}_{x} \mathrm{C}_{y}$ interface, a thin $\mathrm{GeO}_{2}$ layer at the oxide surface, and elemental $\mathrm{Ge}$ at the interface and in the oxide. Due to the segregation of $\mathrm{Ge}$ at the interface, a very high $\left(3-3.6 \times 10^{11} \mathrm{eV}^{-1} \mathrm{~cm}^{-2}\right)$ interface state density was obtained. All the oxides showed electron trapping behavior and the trap generation rate decreased with increasing $\mathrm{C}$ concentration. The charge-to-breakdown value and the oxide breakdown field were higher for $\mathrm{Si}_{1-x} \mathrm{Ge}_{x}$ than $\mathrm{Si}_{1-x} \mathrm{Ge}_{x} \mathrm{C}_{y}$ samples, and these values decreased with increasing $\mathrm{C}$ concentration.

In this work, we investigate further the formation of $\mathrm{SiC}$ precipitates in $\mathrm{Si}_{1-x} \mathrm{Ge}_{x} \mathrm{C}_{y}$ samples using transmission elec-

\footnotetext{
a)Electronic mail: elechoi@nus.edu.sg
}

tron microscopy (TEM). We examine the influence of $\mathrm{C}$ on the film's optical properties by spectroscopic ellipsometry (SE). As the oxides grown at $1000^{\circ} \mathrm{C}$ were shown to be unsatisfactory, we attempted to grow oxides at a lower RTO temperature of $800{ }^{\circ} \mathrm{C}$ in $\mathrm{O}_{2}$ or $\mathrm{N}_{2} \mathrm{O}$. The electrical results of such oxides are reported in this article.

\section{EXPERIMENT}

The $\mathrm{Si}_{1-x-y} \mathrm{Ge}_{x} \mathrm{C}_{y}$ samples were epitaxially grown on $n$-type (100) $\mathrm{Si}$ substrates by RTCVD. ${ }^{8}$ The growth was achieved by heating the substrate with a bank of halogen lamps at $500-600^{\circ} \mathrm{C}$ with a pressure of 1.5 Torr. A Si buffer layer $(200 \mathrm{~nm})$ was grown at $900^{\circ} \mathrm{C}$, followed by the growth of the alloy layer. The process gases were silane $\left(\mathrm{SiH}_{4}\right)$, germane $\left(\mathrm{GeH}_{4}\right)$, methylsilane $\left(\mathrm{SiCH}_{6}\right)$, and hydrogen $\left(\mathrm{H}_{2}\right)$. The alloy thickness was in the range of $50-130 \mathrm{~nm}$.

Rapid thermal oxidation was achieved with an AST SHS 10 rapid thermal processor. Details of the RTO process can be found in our earlier article. ${ }^{6}$ RTO was performed at $800{ }^{\circ} \mathrm{C}$ for $600 \mathrm{~s}$ in dry oxygen $\left(\mathrm{O}_{2}\right)$ or $\mathrm{N}_{2} \mathrm{O}$ ambient. The oxide thickness was found to be between 4 and $5.5 \mathrm{~nm}$. The TEM experiments were carried out using a Philips CM300 system with an operating voltage of $300 \mathrm{kV}$. The SE experiments were performed using a spectroscopic phasemodulated ellipsometer (UVSEL) with the energy ranged from 1.5 to $4.5 \mathrm{eV}$. The rotating polarizer and tracking analyzer were set at $70^{\circ}$. The energy increment and integration time were set at $0.01 \mathrm{eV}$ and $2 \mathrm{~s}$, respectively. The criticalpoint energy $\left(E_{\mathrm{cp}}\right)$ and broadening factor $(\Gamma)$ were obtained by curve fitting the second derivative of the dielectric constant $\left(\epsilon=\epsilon_{1}+i \epsilon_{2}\right)$ versus energy plots using the least-square method.

The electrical properties of the oxides were investigated using the capacitance-voltage $(C-V)$, conductance-voltage $(G-V)$, and the current-voltage $(I-V)$ characteristics of the $\mathrm{Al}-\mathrm{SiO}_{2}-\mathrm{Si}_{1-x-y} \mathrm{Ge}_{x} \mathrm{C}_{y}$ capacitor structure. The $C-V$ 

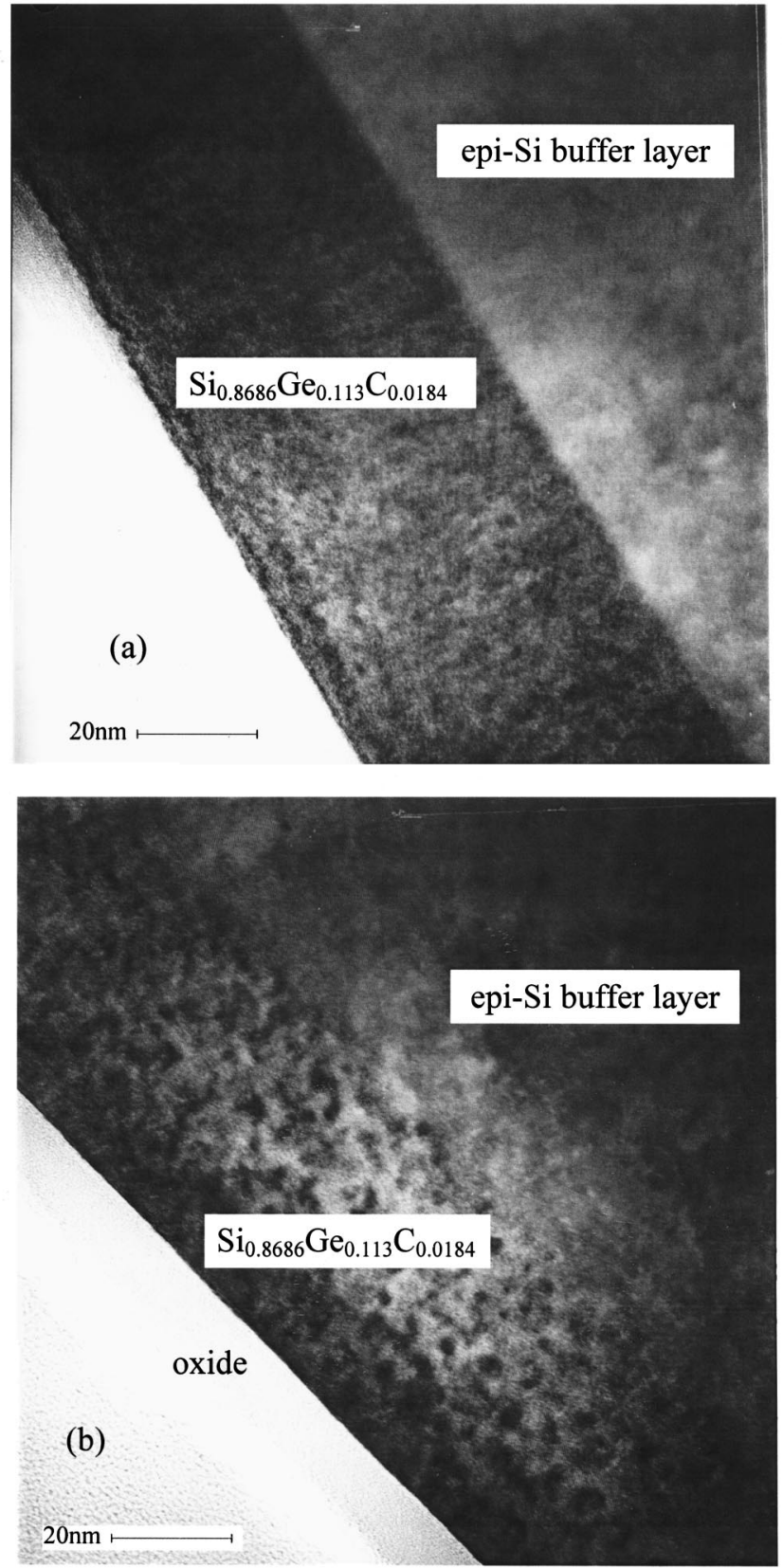

FIG. 1. Typical cross-sectional TEM micrographs of (a) as-grown and (b) rapid thermally oxidized $\mathrm{Si}_{0.8686} \mathrm{Ge}_{0.113} \mathrm{C}_{0.0184}$ samples.

$(G-V)$ and the $I-V$ measurements were carried out using an HP4192 LF impedance analyzer and an HP4156 semiconductor parameter analyzer, respectively.

\section{RESULTS AND DISCUSSION}

\section{A. TEM results}

Figure 1 show typical TEM results of the as-grown and RTO $\mathrm{Si}_{1-x-y} \mathrm{Ge}_{x} \mathrm{C}_{y}$ samples. Figure 1(a) shows a very good interface between $\mathrm{Si}_{0.8686} \mathrm{Ge}_{0.113} \mathrm{C}_{0.0184}$ and the $\mathrm{Si}$ buffer layer. No microtwins or defects can be observed in the asgrown sample. Figure $1(\mathrm{~b})$ shows that after RTO at $1000^{\circ} \mathrm{C}$, there is a lack of sharp interface between $\mathrm{Si}_{0.8686} \mathrm{Ge}_{0.113} \mathrm{C}_{0.0184}$ and the $\mathrm{Si}$ buffer layer. This may be due to $\mathrm{Ge}$ diffused into the $\mathrm{Si}$ substrate as a result of hightemperature oxidation. The whole $\mathrm{Si}_{0.8686} \mathrm{Ge}_{0.113} \mathrm{C}_{0.0184}$ film is also found to contain a significant number of black spots. There are two TEM studies on $\mathrm{SiC}$ formation in $\mathrm{SiGeC}$ films. ${ }^{9,10}$ The SiGeC samples of Warren et al. ${ }^{9}(\mathrm{C}=1 \%)$ and Cuadras et al. ${ }^{10}(\mathrm{C}=0.5 \%)$ exhibited very different $\mathrm{SiC}$ precipitate density. The precipitate density of Warren et al. is similar to our results of Fig. 1(b). It is useful to point out that Strane et al. ${ }^{11}$ also reported a $\mathrm{SiC}$ precipitate distribution in an annealed (at $925^{\circ} \mathrm{C}$ for $190 \mathrm{~min}$ ) $\mathrm{Si}_{0.986} \mathrm{C}_{0.014}$ alloy, very similar to our results.

We have also observed from our TEM results of rapid thermally oxidized $\mathrm{Si}_{0.8811} \mathrm{Ge}_{0.113} \mathrm{C}_{0.0059}$ and $\mathrm{Si}_{0.8738} \mathrm{Ge}_{0.113} \mathrm{C}_{0.0132}$ samples that the $\mathrm{SiC}$ precipitates were significantly lesser than that shown in Fig. 1(b). The TEM results, therefore, agree with our IR results ${ }^{6}$ in that the formation of $\mathrm{SiC}$ precipitates can only be observed in the high-C content RTO samples. We are, however, not able to comment quantitatively on the influence of Ge segregation on the interface state density from the TEM micrographs.

\section{B. SE results}

Figure 2 shows the pseudodielectric function versus photon energy for the as-grown $\mathrm{Si}_{0.887} \mathrm{Ge}_{0.113}$ and $\mathrm{Si}_{0.887-y} \mathrm{Ge}_{0.113} \mathrm{C}_{y}$ alloys. The large amplitudes of the $E_{1}$ and $E_{2}$ gaps of these samples indicate good crystallinity of the films. The energy and peak values of $\epsilon_{2}$ for $\mathrm{Si}_{0.887} \mathrm{Ge}_{0.113}$ are comparable to strained SiGe films. ${ }^{12}$ The amplitudes of $\epsilon_{2}$ at the $E_{1}$ and $E_{2}$ gaps decrease with an increase in C concentration. This is due to the alloying effect and stoichiometric deformation of the films. The humps at the lower edge of the $E_{1}$ gap at 2.6, 2.4, and $2.3 \mathrm{eV}$ for $\mathrm{Si}_{0.8811} \mathrm{Ge}_{0.113} \mathrm{C}_{0.0059}$, $\mathrm{Si}_{0.8738} \mathrm{Ge}_{0.113} \mathrm{C}_{0.0132}$, and $\mathrm{Si}_{0.8686} \mathrm{Ge}_{0.113} \mathrm{C}_{0.0184}$ films may be due to $\mathrm{C}$-related band gaps.

Figure 3(a) shows the energy dependence of the second derivatives of $\epsilon_{1}$ and $\epsilon_{2}$ for the as-grown samples. The results are fitted using the formula develop by Aspnes ${ }^{13}$ assuming two critical points, $E_{1}$ and $E_{0}^{\prime}$. In general, the agreement between the experimental and the simulated results is good.

Figure 4(a) shows the peak positions of $E_{1}$ and $E_{0}^{\prime}$ as a function of $\mathrm{C}$ concentration for the as-grown samples. The $E_{1}$ transition increases linearly with increasing C concentration. The $E_{0}^{\prime}$ transition is independent of $\mathrm{C}$ concentration. The broadening factor of the $E_{1}$ transition for $\mathrm{Si}_{0.887} \mathrm{Ge}_{0.113}$ is $0.137 \mathrm{eV}$ and increases to $0.149,0.157$, and $0.197 \mathrm{eV}$ with $\mathrm{C}$ concentration equal to $0.59 \%, 1.32 \%$, and $1.84 \%$, respectively. Note that the $E_{2}$ peak also broadened but shifts to lower energy. The broadening of the $E_{1}$ and $E_{2}$ peaks may be attributed to the distortion near the carbon atoms and the internal splitting of electronic bands. ${ }^{14}$

Figure 5 compares $\epsilon_{2}$ of the as-grown and RTO samples. The intensity of the $E_{1}$ and $E_{2}$ transitions decreases for all the RTO samples. The $E_{1}$ transition shifts towards the lower energy direction for the RTO samples. This means that the transition occurs from a higher Ge content layer in the samples. The higher Ge content layer could be due to the $\mathrm{Ge}$ piled up at the $\mathrm{SiO}_{2} /$ substrate interface as a result of RTO. As the $E_{1}$ peak for samples $\mathrm{Si}_{0.887} \mathrm{Ge}_{0.113}$ and 

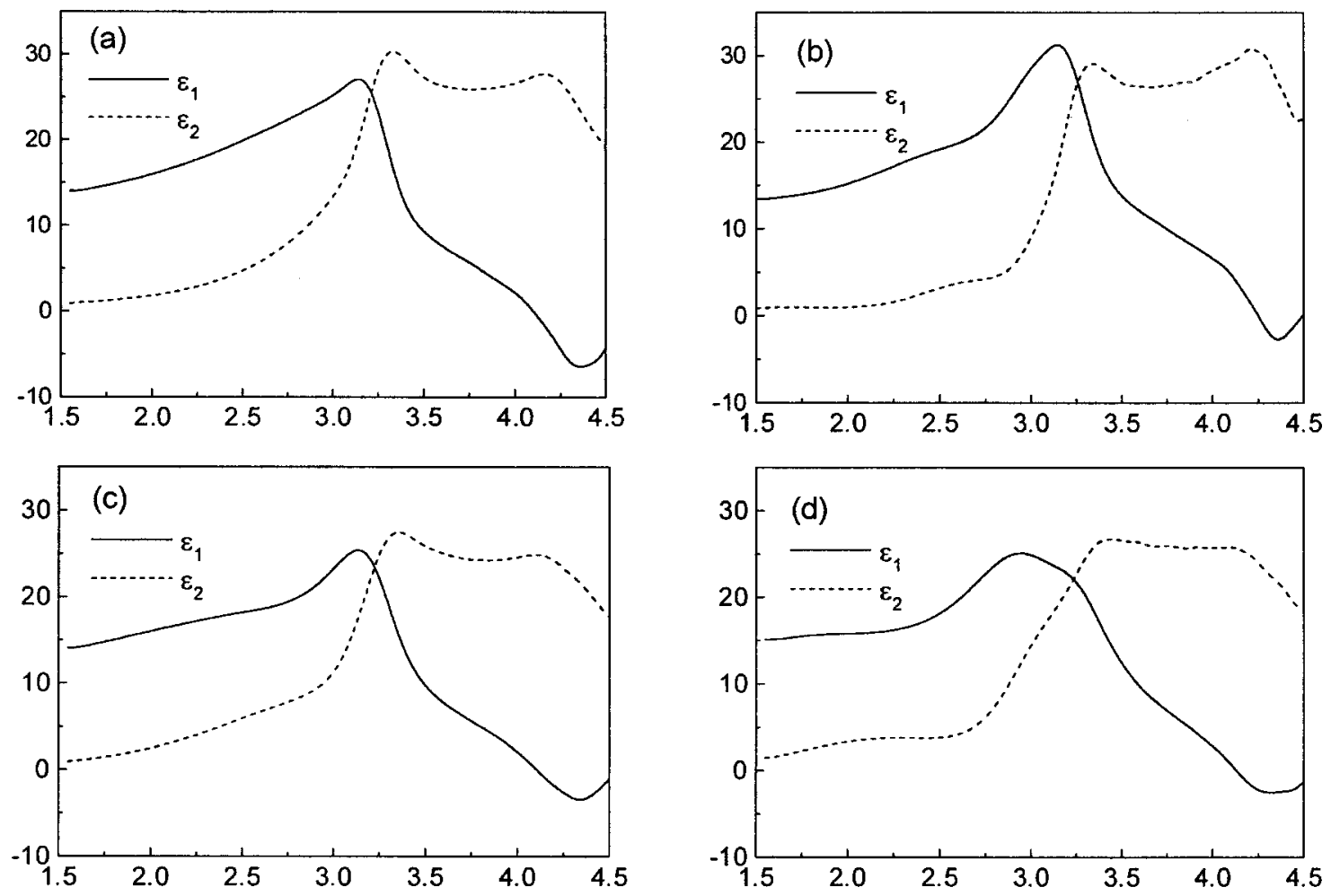

\section{Photon Energy (eV)}

FIG. 2. Pseudodielectric function vs photon energy for the as-grown $\mathrm{Si}_{0.887} \mathrm{Ge}_{0.113}$ and $\mathrm{Si}_{0.887-y} \mathrm{Ge}_{0.113} \mathrm{C}_{y}$ alloys.

$\mathrm{Si}_{0.8811} \mathrm{Ge}_{0.113} \mathrm{C}_{0.0059}$ are located at $3.07 \mathrm{eV}$, this means that the RTO process has reduced most of the $\mathrm{C}$ in the $\mathrm{Si}_{0.8811} \mathrm{Ge}_{0.113} \mathrm{C}_{0.0059}$ film. For samples $\mathrm{Si}_{0.8738} \mathrm{Ge}_{0.113} \mathrm{C}_{0.0132}$ and $\mathrm{Si}_{0.8686} \mathrm{Ge}_{0.113} \mathrm{C}_{0.0184}$, the $E_{1}$ peaks are located at 3.13 and $3.15 \mathrm{eV}$, respectively. These values are lower than the $E_{1}$ peaks of their respective as-grown samples. This suggests a lower C concentration in the RTO samples. This is in good agreement with our previous IR and secondary ion mass spectroscopy (SIMS) results. ${ }^{6}$ The large reduction in $\epsilon_{2}$ intensity at $E_{2}$ in Fig. 5 is due to the presence of an oxide layer.

To study the effect of oxidation on our samples, SE measurements were done after the oxide was etched away. The second derivatives of the pseudodielectric function versus photon energy, and the $E_{1}$ and $E_{0}^{\prime}$ peak versus $C$ content of the etched samples are shown in Figs. 3(b) and 4(b), respectively. As compared to the as-grown samples [Fig. 3(a)], an even better fit between the experimental and theoretical results is obtained for the etched samples. Figure 4(b) shows that the $E_{1}$ transition is weakly dependent on the $\mathrm{C}$ content. This is reasonable as the $\mathrm{C}$ concentrations in the samples were significantly reduced after RTO. With the exception of sample $\mathrm{Si}_{0.887} \mathrm{Ge}_{0.113}$, the $E_{0}^{\prime}$ transition of the etched samples is independent of $\mathrm{C}$ content in the film.

It is worthwhile to note that we have observed ${ }^{5,6}$ no change in the mismatch strain in the $\mathrm{Si}_{0.887} \mathrm{Ge}_{0.113}$ film after RTO at $1000^{\circ} \mathrm{C}$ for $270 \mathrm{~s}$. Therefore, the reduction in the $E_{1}$ value for the RTO $\mathrm{Si}_{0.887} \mathrm{Ge}_{0.113}$ film is unlikely to be due to strain relaxation. On the other hand, we observed a Ge pileup of $\sim 16 \mathrm{~nm}$ at the $\mathrm{SiO}_{2}-\mathrm{SiGe}$ interface after RTO from our SIMS experiments. ${ }^{15}$ We have calculated the penetration depth of the light source used in the SE experiments to be $\sim 20 \mathrm{~nm}$. Therefore, we attribute the reduction in the $E_{1}$ value in the RTO $\mathrm{Si}_{0.887} \mathrm{Ge}_{0.113}$ film to be due to the higher Ge concentration layer. ${ }^{16,17}$

For $\mathrm{SiGeC}$ films, we found that the strain varied from compressive $(C=0.0059)$, fully compensated $(C=0.0132)$ to tensile $(\mathrm{C}=0.0184)$, depending on the carbon concentration in the film. After RTO at $1000^{\circ} \mathrm{C}$ for $270 \mathrm{~s}$, the mismatch strain of the $\mathrm{Si}_{0.8811} \mathrm{Ge}_{0.113} \mathrm{C}_{0.0059}$ and $\mathrm{Si}_{0.8738} \mathrm{Ge}_{0.113} \mathrm{C}_{0.0132}$ films increased to a value comparable to the $\mathrm{Si}_{0.887} \mathrm{Ge}_{0.113}$ film. However, the RTO $\mathrm{Si}_{0.8686} \mathrm{Ge}_{0.113} \mathrm{C}_{0.0184}$ film showed both compressive and tensile strain. Due to the rather complicated patterns in strain for the RTO SiGeC films, it would be inadvisable to discuss the influence of strain on $E_{1}$ without further experiments. On the other hand, we discovered a Ge pileup of similar thickness $(\sim 16 \mathrm{~nm})$ for $\mathrm{SiGeC}$ films at the $\mathrm{SiO}_{2}-\mathrm{SiGeC}$ interface after RTO. ${ }^{7}$ The reduction in the $E_{1}$ values of the RTO $\mathrm{SiGeC}$ films may partially be due to the Ge pileup at the interface. Note that our SE results are in complete agreement with that published by Bonan et al. ${ }^{18}$

Figure 6 shows the refractive indices of the as-grown and etched samples. It is clear that the refractive index increases with an increase in the incident radiation of less than $3.2 \mathrm{eV}$. The increase in the refractive index again indicates the presence of a high-Ge content layer in the etched samples. 

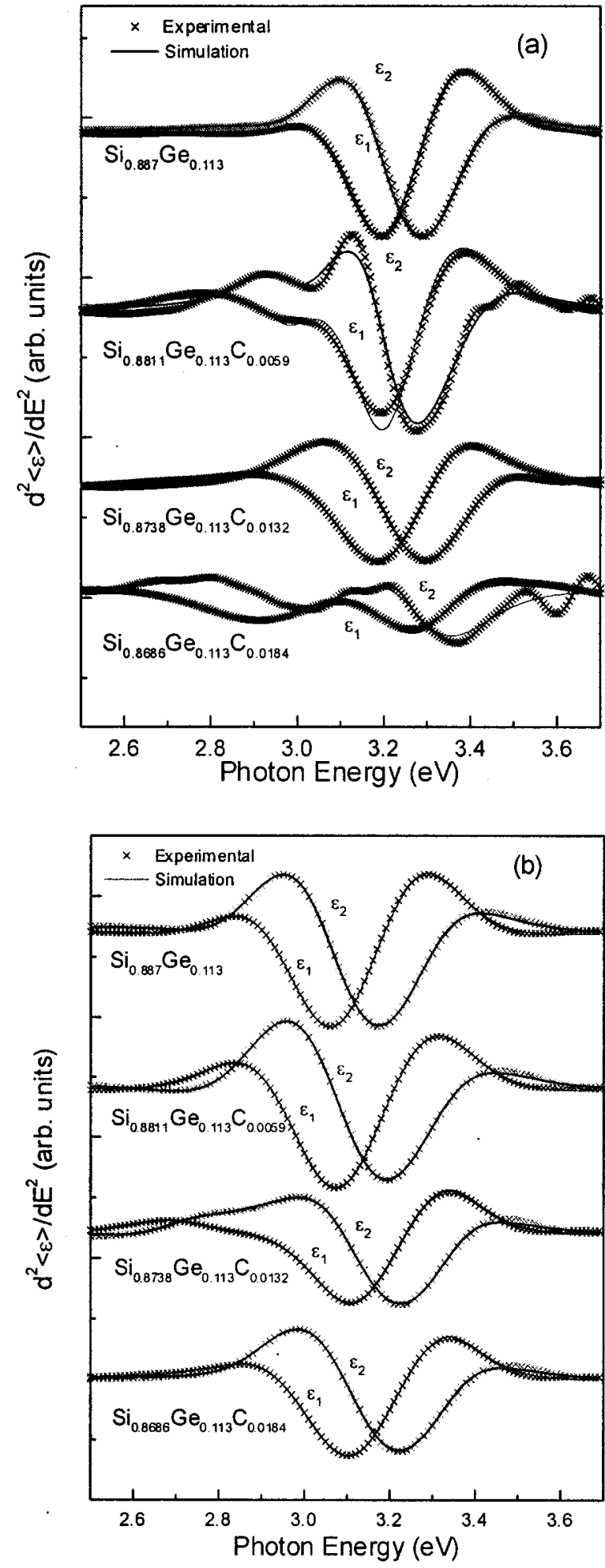

FIG. 3. Second derivatives of the pseudodielectric function of (a) as-grown and (b) RTO samples, with oxide etched away, of $\mathrm{Si}_{0.887} \mathrm{Ge}_{0.113}$ and $\mathrm{Si}_{0.887-y} \mathrm{Ge}_{0.113} \mathrm{C}_{y}$ alloys.

\section{Electrical results}

We have shown previously that rapid thermal oxides grown on $\mathrm{Si}_{0.8738} \mathrm{Ge}_{0.113} \mathrm{C}_{0.0132}$ and $\mathrm{Si}_{0.8686} \mathrm{Ge}_{0.113} \mathrm{C}_{0.0184}$ substrates at $1000^{\circ} \mathrm{C}$ were of poor quality. ${ }^{7}$ We have shown in Sec. III A that significant $\mathrm{SiC}$ precipitation occurred at high-C content $\mathrm{Si}_{1-x-y} \mathrm{Ge}_{x} \mathrm{C}_{y}$ samples after $1000^{\circ} \mathrm{C}$ oxida-
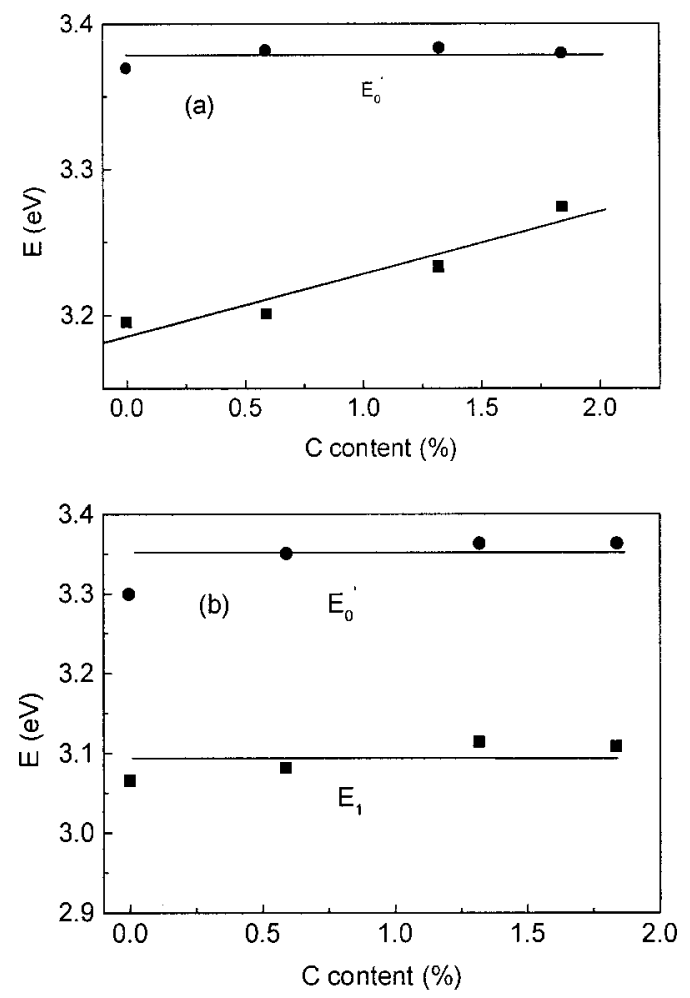

FIG. 4. Energies of the $E_{1}$ and $E_{0}^{\prime}$ critical points of (a) as-grown and (b) RTO samples, with oxide etched away, of $\mathrm{Si}_{0.887} \mathrm{Ge}_{0.113}$ and $\mathrm{Si}_{0.887-y} \mathrm{Ge}_{0.113} \mathrm{C}_{y}$ alloys.

tion. As electrical measurements are nondestructive and simpler in terms of sample preparation, we used the $C-V$ and $I-V$ measurements to explore the possibility of improving the oxide quality. The oxides were grown at a lower RTO temperature of $800{ }^{\circ} \mathrm{C}$ in pure $\mathrm{O}_{2}$ or $\mathrm{N}_{2} \mathrm{O}$ ambient for $600 \mathrm{~s}$. The long oxidation time was to ensure reasonable oxide

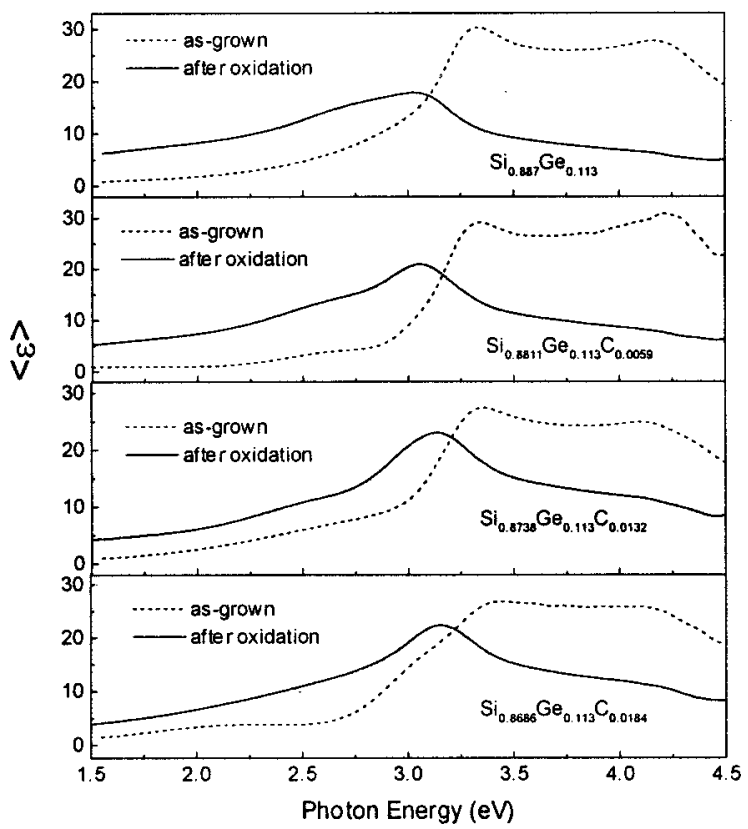

FIG. 5. Imaginary part of the pseudodielectric function of as-grown and RTO $\mathrm{Si}_{0.887} \mathrm{Ge}_{0.113}$ and $\mathrm{Si}_{0.887-y} \mathrm{Ge}_{0.113} \mathrm{C}_{y}$ alloys. 


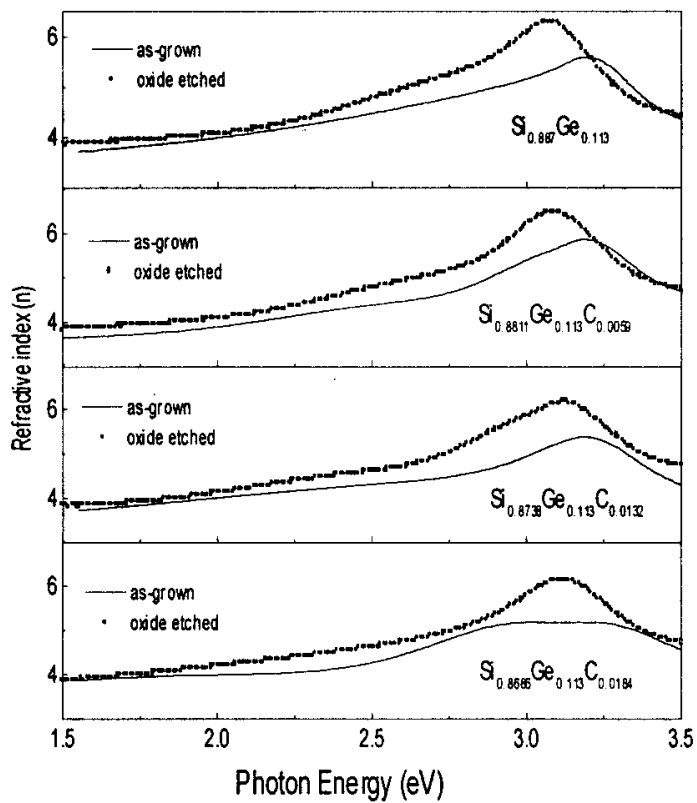

FIG. 6. Refractive indices of as-grown and $\mathrm{RTO} \mathrm{Si}_{0.887} \mathrm{Ge}_{0.113}$ and $\mathrm{Si}_{0.887-y} \mathrm{Ge}_{0.113} \mathrm{C}_{y}$ alloy films.

thickness was obtained. We have chosen the $\mathrm{Si}_{1-x-y} \mathrm{Ge}_{x} \mathrm{C}_{y}$ substrate with the lowest $\mathrm{C}$ content (i.e., $\left.\mathrm{Si}_{0.8811} \mathrm{Ge}_{0.113} \mathrm{C}_{0.0059}\right)$ to minimize $\mathrm{SiC}$ precipitation. The electrical results of $\mathrm{Al}-\mathrm{SiO}_{2}-\mathrm{Si}_{0.887} \mathrm{Ge}_{0.113}$ capacitors were included for comparison purposes.

We found that thinner oxides were obtained when grown in $\mathrm{N}_{2} \mathrm{O}$ ambient as compared to $\mathrm{O}_{2}$ ambient for both $\mathrm{Si}_{0.887} \mathrm{Ge}_{0.113}$ and $\mathrm{Si}_{0.8811} \mathrm{Ge}_{0.113} \mathrm{C}_{0.0059}$ substrates (see Table I). This is expected, as oxide growth is always slower in $\mathrm{N}_{2} \mathrm{O}$ as compared to $\mathrm{O}_{2}$.

The $I-V$ characteristics of oxides grown on $\mathrm{Si}_{0.887} \mathrm{Ge}_{0.113}$ and $\mathrm{Si}_{0.8811} \mathrm{Ge}_{0.113} \mathrm{C}_{0.0059}$ substrates in $\mathrm{N}_{2} \mathrm{O}$ or $\mathrm{O}_{2}$ ambient are shown in Fig. 7. The conductivities of oxides (calculated at $4 \mathrm{MV} / \mathrm{cm}$ ) grown in $\mathrm{O}_{2}$ (see Table $\mathrm{I}$ ) are in the range between $1.0 \times 10^{-14}$ and $2.5 \times 10^{-15} \Omega^{-1} \mathrm{~cm}^{-1}$. These are reasonable values as the oxides were grown at a relatively low temperature of $800^{\circ} \mathrm{C}$. We can only observe the Fowler-Nordheim transport mechanism in the $\mathrm{Si}_{0.887} \mathrm{Ge}_{0.113}$ samples. The onset of Fowler-Nordheim conduction is at $\sim 6 \mathrm{MV} / \mathrm{cm}$. A barrier height of $2.54 \mathrm{eV}$ was obtained from the Folwer-Nordheim plot for the $\mathrm{SiO}_{2}-\mathrm{Si}_{0.887} \mathrm{Ge}_{0.113}$ system. The lower value for the $\mathrm{SiO}_{2}-\mathrm{Si}_{0.887} \mathrm{Ge}_{0.113}$ system (c.f. to the $\mathrm{Si}-\mathrm{SiO}_{2}$ system) may be due to the rougher interface.

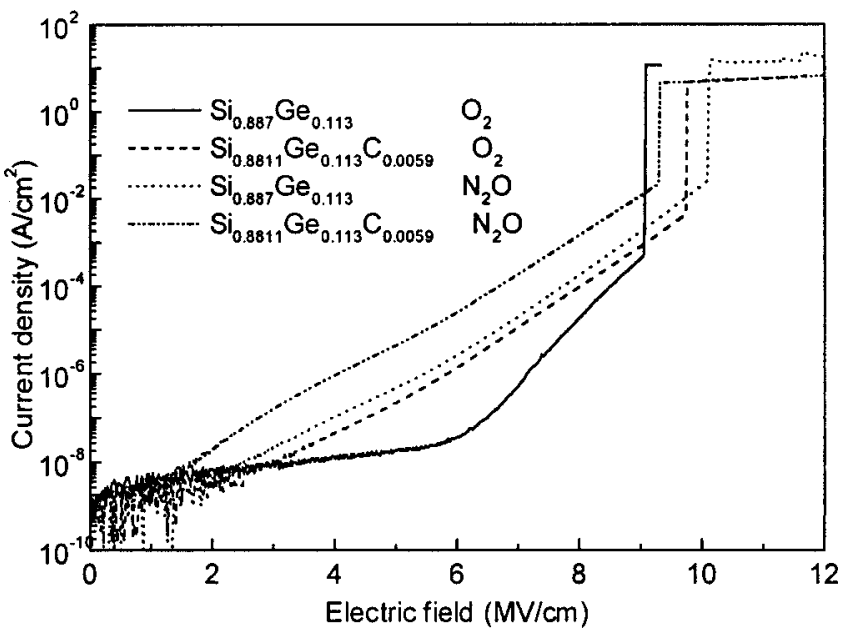

FIG. 7. $I-V$ characteristics of oxides grown on $\mathrm{Si}_{0.887} \mathrm{Ge}_{0.113}$ and $\mathrm{Si}_{0.8811} \mathrm{Ge}_{0.113} \mathrm{C}_{0.0059}$ substrates in $\mathrm{N}_{2} \mathrm{O}$ or $\mathrm{O}_{2}$ ambient.

The sample with the $\mathrm{Si}_{0.8811} \mathrm{Ge}_{0.113} \mathrm{C}_{0.0059}$ substrate shows a rapid increase in current for an electric field exceeding 4 $\mathrm{MV} / \mathrm{cm}$. It is interesting to note that oxides grown on the $\mathrm{Si}_{0.887} \mathrm{Ge}_{0.113}$ and $\mathrm{Si}_{0.8811} \mathrm{Ge}_{0.113} \mathrm{C}_{0.0059}$ substrates with $\mathrm{N}_{2} \mathrm{O}$ ambient are more leaky $\left(\sigma=1.5-2.55 \times 10^{-13} \Omega^{-1} \mathrm{~cm}^{-1}\right)$ than the corresponding samples grown in $\mathrm{O}_{2}$ ambient. Also, the conductivities of the $800{ }^{\circ} \mathrm{C}$ oxides are generally $2-3$ orders of magnitude higher than the $1000{ }^{\circ} \mathrm{C}$ oxides. The breakdown field of the $800{ }^{\circ} \mathrm{C}$ oxide on the $\mathrm{Si}_{0.887} \mathrm{Ge}_{0.113}$ substrate grown in $\mathrm{N}_{2} \mathrm{O}$ is higher than that grown in $\mathrm{O}_{2}$. Note that the breakdown fields for all the oxides grown at $800^{\circ} \mathrm{C}$ are significantly lower than the breakdown field $(10-14 \mathrm{MV} / \mathrm{cm})$ of oxides grown at $1000^{\circ} \mathrm{C}$.

Figure 8 shows the high-frequency $(1 \mathrm{MHz}) C-V$ characteristics of the metal-oxide-semiconductor (MOS) structures with $\mathrm{Si}_{0.887} \mathrm{Ge}_{0.113}$ and $\mathrm{Si}_{0.8811} \mathrm{Ge}_{0.113} \mathrm{C}_{0.0059}$ substrates. The substrate doping concentrations derived from the $C-V$ curves are listed in Table I. Taking a relative permittivity of the $\mathrm{Si}_{0.887} \mathrm{Ge}_{0.113}$ and $\mathrm{Si}_{0.8811} \mathrm{Ge}_{0.113} \mathrm{C}_{0.0059}$ films to be $\sim 12.4$, the maximum depletion widths are estimated to be $\sim 400$ and $40 \mathrm{~nm}$, respectively. For the $\mathrm{Si}_{0.887} \mathrm{Ge}_{0.113}$ film, the maximum depletion width will be extended into the $\mathrm{Si}$ buffer layer. The $\mathrm{Si}$ buffer layer had a doping concentration of $5 \times 10^{15}-1$ $\times 10^{16} \mathrm{~cm}^{-3}$. This has resulted in a doping concentration of $5.56 \times 10^{15}-1.56 \times 10^{16} \mathrm{~cm}^{-3}$ for the RTO $\mathrm{Si}_{0.887} \mathrm{Ge}_{0.113}$ films. For the RTO $\mathrm{Si}_{0.8811} \mathrm{Ge}_{0.113} \mathrm{C}_{0.0059}$ film, the maximum depletion width is well inside the $\mathrm{SiGeC}$ layer. Table I shows

TABLE I. Oxide thickness, conductivity, breakdown field, and the interface state density of RTO oxides grown at $800{ }^{\circ} \mathrm{C}$ and the doping concentration on $\mathrm{Si}_{0.887} \mathrm{Ge}_{0.113}$ and $\mathrm{Si}_{0.8686} \mathrm{Ge}_{0.113} \mathrm{C}_{0.0059}$ substrates. Also included here for comparison are the oxide thickness, conductivity, breakdown field, and interface state density of RTO oxides grown at $1000{ }^{\circ} \mathrm{C}$ in $\mathrm{O}_{2}$ on the same substrates.

\begin{tabular}{|c|c|c|c|c|c|c|}
\hline Sample & $\begin{array}{c}\text { RTO } \\
\text { condition }\end{array}$ & $\begin{array}{c}\text { Oxide } \\
\text { thickness }(\mathrm{nm})\end{array}$ & $\begin{array}{c}\sigma \\
\left(\Omega^{-1} \mathrm{~cm}^{-1}\right)\end{array}$ & $\begin{array}{c}E_{\mathrm{bd}} \\
(\mathrm{MV} / \mathrm{cm})\end{array}$ & $\begin{array}{l}\text { Doping } \\
\left(\mathrm{cm}^{-3}\right)\end{array}$ & $\begin{array}{c}D_{\mathrm{it}} \\
\left(\mathrm{cm}^{-2} \mathrm{eV}^{-1}\right)\end{array}$ \\
\hline \multirow[t]{3}{*}{$\mathrm{Si}_{0.887} \mathrm{Ge}_{0.113}$} & $\mathrm{O}_{2}\left(800^{\circ} \mathrm{C}\right)$ & 5.4 & $2.50 \times 10^{-15}$ & 9.06 & $1.56 \times 10^{16}$ & $1.62 \times 10^{12}$ \\
\hline & $\mathrm{N}_{2} \mathrm{O}\left(800^{\circ} \mathrm{C}\right)$ & 4.0 & $2.50 \times 10^{-13}$ & 10.10 & $5.56 \times 10^{15}$ & $2.42 \times 10^{12}$ \\
\hline & $\mathrm{O}_{2}\left(1000^{\circ} \mathrm{C}\right)$ & 17.9 & $3.98 \times 10^{-16}$ & 12.53 & $6.70 \times 10^{15}$ & $3.00 \times 10^{11}$ \\
\hline \multirow[t]{3}{*}{$\mathrm{Si}_{0.8811} \mathrm{Ge}_{0.113} \mathrm{C}_{0.0059}$} & $\mathrm{O}_{2}\left(800^{\circ} \mathrm{C}\right)$ & 4.3 & $1.00 \times 10^{-14}$ & 9.75 & $1.06 \times 10^{16}$ & $2.27 \times 10^{12}$ \\
\hline & $\mathrm{N}_{2} \mathrm{O}\left(800^{\circ} \mathrm{C}\right)$ & 4.1 & $1.50 \times 10^{-13}$ & 9.30 & $1.30 \times 10^{16}$ & $2.96 \times 10^{12}$ \\
\hline & $\mathrm{O}_{2}\left(1000^{\circ} \mathrm{C}\right)$ & 12.5 & $7.96 \times 10^{-16}$ & 12.81 & $5.70 \times 10^{17}$ & $1.10 \times 10^{12}$ \\
\hline
\end{tabular}




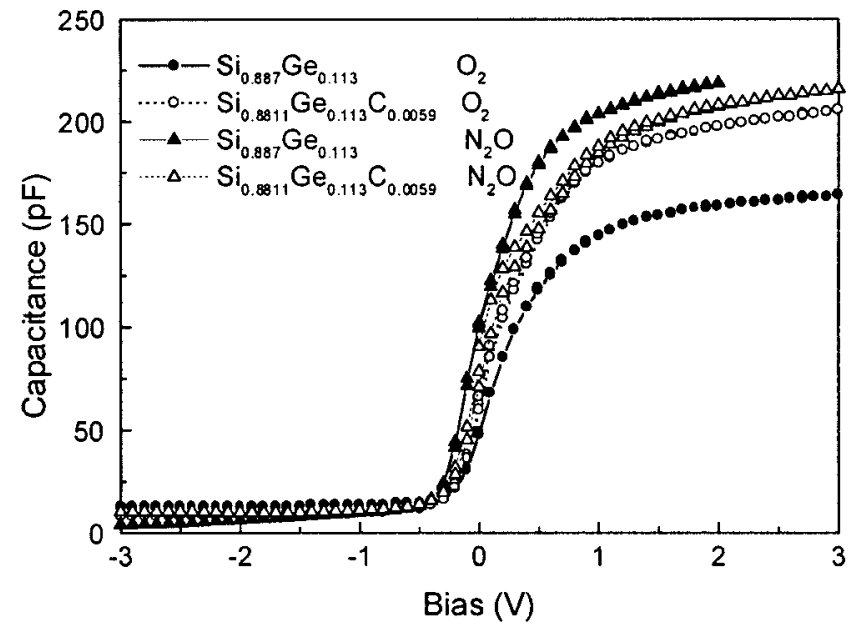

FIG. 8. High-frequency (1 MHz) $C-V$ characteristics of the MOS structures with $\mathrm{Si}_{0.887} \mathrm{Ge}_{0.113}$ and $\mathrm{Si}_{0.8811} \mathrm{Ge}_{0.113} \mathrm{C}_{0.0059}$ substrates.

that the $\mathrm{Si}_{0.8811} \mathrm{Ge}_{0.113} \mathrm{C}_{0.0059}$ samples have a higher doping concentration than the $\mathrm{Si}_{0.887} \mathrm{Ge}_{0.113}$ samples. This agrees with the report of Osten and Gaworzewski ${ }^{19}$ in that $\mathrm{C}$ in the $\mathrm{Si}_{0.8811} \mathrm{Ge}_{0.113} \mathrm{C}_{0.0059}$ sample would introduce donor-like centers $^{20}$ and increase the doping concentration. The doping concentrations of $\mathrm{Si}_{0.8811} \mathrm{Ge}_{0.113} \mathrm{C}_{0.0059}$ samples RTO at 800 and $1000{ }^{\circ} \mathrm{C}$ in $\mathrm{O}_{2}$ are $1.06 \times 10^{16}$ and $5.7 \times 10^{17} \mathrm{~cm}^{-3}$, respectively. This means that the increase in the doping concentration may also be linked to the formation of SiC precipitates in the films.

The interface state densities $\left(D_{\text {it }}\right)$ of our samples, calculated from the Hill and Coleman method, ${ }^{21}$ are listed in Table I. Note that these $D_{\text {it }}$ values were obtained at a depletion width (31-69 nm for $\mathrm{Si}_{0.887} \mathrm{Ge}_{0.113}$ and 20-33 nm for $\mathrm{Si}_{0.8811} \mathrm{Ge}_{0.113} \mathrm{C}_{0.0059}$ samples), well within the thickness of the $\mathrm{Si}_{0.887} \mathrm{Ge}_{0.113}$ and $\mathrm{Si}_{0.8811} \mathrm{Ge}_{0.113} \mathrm{C}_{0.0059}$ layers. Significant higher $D_{\text {it }}$ values $\left(1.62-2.96 \times 10^{12} \mathrm{eV}^{-1} \mathrm{~cm}^{-1}\right)$ were obtained for the $800^{\circ} \mathrm{C}$ oxides. The $D_{\text {it }}$ values of oxides grown at $1000{ }^{\circ} \mathrm{C}$ with the $\mathrm{Si}_{0.887} \mathrm{Ge}_{0.113}$ and $\mathrm{Si}_{0.8811} \mathrm{Ge}_{0.113} \mathrm{C}_{0.0059}$ substrates are $3.0 \times 10^{11}$ and $1.1 \times 10^{12} \mathrm{eV}^{-1} \mathrm{~cm}^{-1}$, respectively. We can, therefore, conclude that a lower oxidation temperature is not suitable in reducing $D_{\mathrm{it}}$. We have used the metal work function between $\mathrm{Al}$ and $\mathrm{Si}$ to estimate the $Q_{f}$ values of the MOS structure with oxide grown at 800 and $1000^{\circ} \mathrm{C}$ on the $\mathrm{Si}_{0.887} \mathrm{Ge}_{0.113}$ substrate to be $-1.14 \times 10^{12}$ and $-9.5 \times 10^{11} \mathrm{~cm}^{-2}$, respectively. This again indicates that a lower oxidation temperature resulted in a higher fixed charge value in the oxide. Ahn et al. ${ }^{22}$ have suggested that the negative fixed charge observed in the $\mathrm{SiGe}$ system was a result of $\mathrm{Si}-\mathrm{O}-$ dangling bonds in the oxide. The larger $Q_{f}$ value in the $800{ }^{\circ} \mathrm{C}$ (as compared to the $1000{ }^{\circ} \mathrm{C}$ sample) may be due to the higher amount of $\mathrm{Si}-\mathrm{O}-$ dangling bonds that exist in the oxide. We are not able to compare the $Q_{f}$ results of the $\mathrm{Si}_{0.8811} \mathrm{Ge}_{0.113} \mathrm{C}_{0.0059}$ samples as the $1000^{\circ} \mathrm{C}$ showed a rather abnormal trend with the $\mathrm{C}$ content in the film.

\section{CONCLUSIONS}

The TEM results showed a significant $\mathrm{SiC}$ precipitation in the high-C content $\mathrm{Si}_{1-x-y} \mathrm{Ge}_{x} \mathrm{C}_{y}$ sample after RTO. The
SE results showed that the $E_{1}$ gap increased and $E_{2}$ gap decreased as the $\mathrm{C}$ concentration increased. For the RTO samples, the amplitude of the $E_{2}$ transitions reduced rapidly and the $E_{1}$ transition shifted to a lower energy. The reduction of the amplitude of the $E_{2}$ transitions is due to the presence of the oxide layer. The refractive indices of the RTO samples were higher compared to the as-grown films. A high-Ge content layer and the low-C content in the RTO films accounted for the $E_{1}$ shift to lower energy and the increase of the refractive index. We conclude from the electrical measurements that RTO at a lower temperature of $800^{\circ} \mathrm{C}$ did not improve the oxide quality as compared to $1000^{\circ} \mathrm{C}$.

\section{ACKNOWLEDGMENTS}

The authors would like to thank C. H. Tung of the Institute of Microelectronics for his help in the TEM work, S. I. Pang of the Data Storage Institute for the help in the SE experiments. The provisions of a Research and Development Grant (GR6471) by the National Science and Technology Board and a research fellowship for one of the authors (L.K.B.) and a research scholarship for one of the authors (F.W.) by the University are gratefully acknowledged.

${ }^{1}$ G. L. Patton et al., IEEE Electron Device Lett. 11, 171 (1990).

${ }^{2}$ R. Karunasiri, J. S. Park, and K. L. Wang, Appl. Phys. Lett. 59, 2588 (1991)

${ }^{3}$ Y. Rajakarumamayake and T. McGill, J. Vac. Sci. Technol. B 8, 929 (1990)

${ }^{4}$ Y. Mii, Y. Xie, E. Fitzgerald, D. Monroe, F. Thiel, B. Weir, and L. Feldman, Appl. Phys. Lett. 59, 1611 (1991)

${ }^{5}$ W. K. Choi, L. K. Bera, J. H. Chen, W. Feng, K. L. Pey, H. Yoong, J. Mi, F. Zhang, and C. Y. Yang, Mater. Sci. Eng., B 75, 184 (2000).

${ }^{6}$ W. K. Choi, J. H. Chen, L. K. Bera, W. Feng, K. L. Pey, J. Mi, C. Y. Yang, A. Ramam, S. J. Chua, J. S. Pan, A. T. S. Wee, and R. Liu, J. Appl. Phys. 87, 192 (2000).

${ }^{7}$ L. K. Bera, W. K. Choi, W. Feng, C. Y. Yang, and J. Mi, Appl. Phys. Lett. 77, 256 (2000).

${ }^{8}$ J. Mi, P. Warren, P. Letourneau, M. Judelewicz, M. Gaihanou, M. Dutoit, C. Dubois, and J. C. Dupuy, Appl. Phys. Lett. 67, 259 (1995).

${ }^{9}$ P. Warren, J. Mi, F. Overney, and M. Dutoit, J. Cryst. Growth 157, 414 (1995).

${ }^{10}$ A. Cuadras, B. Carrido, C. Bonafos, J. R. Morante, L. Fonseca, and K. Pressel, Microelectron. Reliab. 40, 829 (2000).

${ }^{11}$ J. W. Strane, H. J. Stein, S. R. Lee, S. T. Picraux, J. K. Watanabe, and J. W. Mayer, J. Appl. Phys. 76, 3656 (1994).

${ }^{12}$ H. Lee, Thin Solid Films 313-314, 167 (1998).

${ }^{13}$ D. E. Aspnes, in Handbook on Semiconductors (North-Holland, Amsterdam, 1980), Vol. 2, p. 109.

${ }^{14}$ B. Dietrich, H. J. Osten, H. Rucker, M. Methfessel, and P. Zaumseil, Phys. Rev. B 49, 17185 (1994).

${ }^{15}$ J. H. Chen, MEng thesis, National University of Singapore (1999).

${ }^{16}$ J. Humlicek, M. Garriga, M. I. Alonso, and M. Cardona, J. Appl. Phys. 65, 2827 (1989)

${ }^{17}$ C. Pickering, R. T. Carline, D. J. Robbins, W. Y. Leong, S. J. Barnett, A. D. Pitt, and A. G. Cullis, J. Appl. Phys. 73, 239 (1993).

${ }^{18}$ J. Bonan, F. Meyer, E. Finkman, P. Warren, and P. Boher, Thin Solid Films 364, 53 (2000).

${ }^{19}$ H. J. Osten and P. Gaworzewski, J. Appl. Phys. 82, 4977 (1997).

${ }^{20}$ B. Carrido, J. Morante, M. Franz, K. Pressel, D. Krüger, P. Zaumseil, and H. J. Osten J. Appl. Phys. 85, 833 (1999).

${ }^{21}$ W. A. Hill and C. C. Coleman, Solid-State Electron. 23, 987 (1980).

${ }^{22}$ C. G. Ahn, H. S. Kang, Y. K. Kwon, S. M. Lee, B. R. Ryum, and B. K. Kang, J. Appl. Phys. 86, 1542 (1999). 